\title{
The Arab Spring and Water Security
}

\author{
MUHAMMAD SHATANAWI
}

UNESCO Chair in Wadi Hydrology, University of Jordan, Amman, Jordan

m.r.shatanawi@gmail.com, shatanaw@ju.edu.jo

\section{INTRODUCTION}

Most of the Arab countries are located in the arid to semi-arid parts of the world which are characterised by limited water resources and fragile ecosystems. The amount of available water resources is about 265 million cubic metres (MCM) compared to a total population of 370 million people, putting the per capita share of water at less than 1000 cubic metres (ESCWA 2013). Thirteen of the 20 states that make up the Arab world rank among the most-scarce nations globally, and suffer severe water stress (World Bank 2009a).

High rates of population growth, urbanization, industrialization and other economic activities, as well as the effects of climate change and occurrence of droughts, add to the stress and raise the spectre of continuous water shortages in the near future. The land and water resources of the Fertile Crescent and the Nile Valley, that once fed the people of Middle East, are no longer sufficient due to the unprecedented population increase. Shortages of water resources that are necessary for food production have acted as a major stress factor and have exacerbated other environmental and social stresses. The reports of the Arab Organization for Agricultural Development (2012) and the World Bank (2009b) indicate that more than 50\% of the food consumed in the region is imported. This paper discusses the role of water shortage and climate change in igniting the Arab Spring and its effect on water and food security. It also discusses the consequences of the Arab Spring on water security.

\section{THE ROLES OF WATER SHORTAGE AND CLIMATE CHANGE}

In addition to the shortage of water, lack of food and increased food prices, other social and political factors have influenced the political stability, uprising and protest as well as regime changes in Tunisia, Egypt, Libya and Yemen. These factors include among others: social inequity, corruption, authoritarian regimes, unemployment and lack of democracy. The Arab Spring did not come out of the blue but is the resultant of all the above factors. The unemployment rate among the young generation and university graduates has reached an average of $25 \%$ compared to the global average of $12.4 \%$ (Warrell and Femina 2013). Young people cannot work in rural areas and instead move to cities where they still cannot find jobs. The growing frustration among these youth pushed them to the street in protest. According to the opinion of different experts, food insufficiency caused by water shortage may not be the principle cause of the uprising but was an aggravating factor, while others think that it was the root of the problem. Water shortages in most Arab countries are not caused by a single reason but rather a complex interaction of several variables including climate change, competition for resources between countries and various sectors, as well as by increased demand for and mismanagement of natural resources.

Arab states are located downstream of shared rivers while other riparian countries, such as Turkey and Ethiopia, control the headwaters. The upstream usage and water storage behind dams for irrigation in Turkey have decreased the share of water for Syria and Iraq, and have affected the quality of water from the Euphrates and Tigris. The case of the Nile is rather different whereby eight states, led by Ethiopia, demand modification of the 1929 agreement claiming an equitable share of the river's water. Ethiopia is pressing ahead with construction of a major hydropower dam on the Blue Nile known as the Grand Ethiopian Renaissance Dam. The dam, slated to begin operation in 2017, will reduce the downstream flow of the Nile by $20 \%$ to $30 \%$, and so reduce by nearly a third the electricity generated by the High Dam. This conflict comes at a time when different parts of Egypt are already suffering from a shortage of water. The problem came to Egypt 
during a period of unrest and unhealthy dialogue between the government and opposition where every party was putting the blame on the other side. What will be the reaction of Egypt after the election of the new president and the establishment of a stable government? What will be the effect of the new dam on water and the national security?

\section{CONSEQUENCES}

Prior to the Arab Spring, the Levant countries experienced a long drought from 2006 to 2011, causing significant reduction in wheat production in rainfed areas and forcing many farmers to migrate to cities. For example, about one million people left rural areas in Syria to move to the suburbs of big cities, thus increasing the number of unemployed and under privileged people. The problem of water shortages is compounded by bad management and poor governance. While poor farmers were not allowed to drill wells, major aquifers were heavily exploited by big companies and influential people. Enforcing regulation of groundwater control by severe punishment, without finding alternatives, might create unrest and trigger protests.

The Syrian crisis has impacted the natural resources not only of Syria, but extending to Jordan and Lebanon; both host more than 2.5 million refugees. According to the Reach Report (2014), more than 567000 refugees have been registered in Jordan while there could be similar number unregistered including migrants working in Jordan, making 1.2 million in total which represents $15 \%$ of the entire population. It has been estimated that the population in Jordan could jump to 9.0 million people and the per capita share of water drop from 140 to 110 cubic metres, which will turn Jordan's chronic water shortage into a crisis. About 140000 of the registered refugees are living in camps, mostly in the Mafraq area, which are built over the major aquifers of Azraq and Yarmouk so increasing the risk of groundwater pollution. About the same number of Syrians are living or working in Lebanon and have put a huge pressure on the host committee by increasing housing rent prices, competition for jobs and investment, demanding more of public services and competition for natural resources. In Syria as well as in Iraq, the opposition have control over major water resources and hydraulic structures. However, there is a fear that they could be misused or left without maintenance. The situation in Syria regarding infrastructure for water supply and sanitation is not known. For example, Adra, a city of major confrontation during the conflict, hosts the largest wastewater treatment plant in Syria; its status is unknown.

\section{CONCLUSION}

If the unrest continues in the Arab Spring countries, internal security will take priority over other developments plans including those for water supply and sanitation, maintaining hydraulic structures and modernization of irrigation schemes. Therefore, these countries should pass the transition period quickly in order to direct their efforts towards addressing the challenge of water and food security, and starting cooperation with neighbouring states to solve issues of shared water resources. Without proper management and good governance, water shortages and increased food prices may spark violence worse than the Arab spring.

\section{REFERENCES}

AOAD (2012) Arab Food Security Report. Arab Organization for Agricultural Development (AOAD), Khartoum, Sudan. ESCWA (2013) Water Development Report 5: Issues in sustainable water resources management and water services. Economic and Social Commission for Western Asia (ESCWA), Beirut, Lebanon.

REACH (2014) Evaluation of the effect of the Syrian refugee crisis: stability and resilience in Jordanian host communities. A report prepared by REACH project, supported by the British Embassy in Amman, UNHCR and UNICEF.

Werrell, G.E. and Femia, F. (2013) The Arab Spring and Climate Change. The Centre for Climate and Security and the Centre for American Progress, Washington, DC.

World Bank (2009a) Making the most of scarcity: accountability for better water management in the Middle East and North Africa. Washington, DC.

World Bank (2009b) Improving Food Security in the Arab World. Report prepared jointly by the World Bank, FAO and IFAD. 